\title{
Validation of a diagrammatic scale for quantification of bacterial leaf blight (causal agent Pseudomonas avenae) in maize
}

\section{Validação de escala diagramática para quantificação da mancha bacteriana da folha (causada por Pseudomonas avenae) em milho}

\author{
Eloisa Lorenzetti ${ }^{1 *}$; Juliano Tartaro ${ }^{2}$; José Renato Stangarlin ${ }^{3}$; Roberto Luis Portz ${ }^{1}$; \\ Odair José Kuhn ${ }^{3}$; Alfredo José Alves Neto ${ }^{4}$
}

Highlights:

Unprecedented diagrammatic scale for quantification of bacterial leaf spot in corn.

Scale to evaluate the severity of bacterial leaf spot in corn improves accuracy and precision.

Very useful tool which facilitates and accelerates evaluations.

\begin{abstract}
Bacterial leaf blight occurs in almost the entire Brazilian territory and can cause significant economic damage. However, its effects can be curtailed with the following tools that aid in quantification for carrying out the best severity assessment that can be applied to the studies used in its control. The objective of this study was to develop and validate a diagrammatic scale to quantify the severity of bacterial leaf blight in maize caused by Pseudomonas avenae. Corn leaves were collected with different levels of disease severity, and the total leaf area as well as the injured area of the middle third of each leaf was measured. From this, the minimum and maximum limits of the disease and, subsequently, four intermediate levels were determined whilst taking into account the law of visual stimulus of WeberFechner. Levels $1.5 \%, 2.5 \%, 9 \%, 18 \%, 46 \%$, and $70 \%$ were selected with validation performed by eight evaluators, four inexperienced and four experienced. These evaluators estimated the severity values, initially without the use of the proposed diagrammatic scale and in a second attempt with the use of the scale. We concluded that it was possible to improve the accuracy and precision of the evaluators when they used the scale as a tool to assess the severity of bacterial leaf blight on corn leaves.
\end{abstract}

Key words: Disease assessment. Pathometry. Zea mays L.

\section{Resumo}

A mancha bacteriana da folha ocorre em praticamente todo o território brasileiro e pode causar perdas econômicas significativas sendo necessárias ferramentas que auxiliem na sua quantificação a fim de realizar melhor avaliação de severidade podendo contribuir em estudos visando seu controle. Diante do exposto, o objetivo deste estudo foi desenvolver e validar a escala diagramática para quantificação da severidade da mancha bacteriana da folha em milho causada por Pseudomonas avenae. Foram coletada

\footnotetext{
1 Profs., Universidade Federal do Paraná, UFPR, Palotina, PR, Brasil. E-mail: eloisa-lorenzetti@hotmail.com; portz_r@hotmail.com

2 Eng $^{\circ}$ Agro, Universidade Estadual do Oeste do Paraná, UNIOESTE, Marechal Cândido Rondon, PR, Brasil. E-mail: julianotartaro@hotmail.com

3 Profs., UNIOESTE, Marechal Cândido Rondon, PR, Brasil. E-mail: jose.stangarlin@unioeste.br; ojkuhn@gmail.com

4 Discente do Curso de Doutorado do Programa de Pós-Graduação em Agronomia, UNIOESTE, Marechal Cândido Rondon, PR, Brasil. E-mail: alfredo.alves.neto@hotmail.com

* Author for correspondence
} 
folhas de milho apresentando diferentes níveis de severidade da doença, e mediu-se a área foliar total e a área lesionada do terço médio de cada uma das folhas, determinando-se os limites mínimo e máximo da doença, e, posteriormente, os quatro níveis intermediários levando em consideração a lei do estímulo visual de Weber-Fechner. Foram selecionados os níveis 1,5\%, 2,5\%, 9\%, 18\%, 46\%, e 70\%, sendo a validação realizada por oito avaliadores, quatro inexperientes e quatro experientes, que estimaram os valores de severidade inicialmente sem a utilização da escala diagramática proposta, e num segundo momento com a utilização da escala. Conclui-se que foi possível melhorar a acurácia e a precisão dos avaliadores quando estes utilizaram a escala como ferramenta para avaliação de severidade para mancha bacteriana da folha do milho.

Palavras-chave: Quantificação de doença. Patometria. Zea mays L.

\section{Introduction}

Bacterial leaf blight is caused by the bacterium Pseudomonas avenae, which has a sporadic occurrence and has already been reported in all regions of Brazil. The development of the disease occurs during rainy periods or in areas of significant irrigation, and is favored by high temperatures (Carvalho, Pereira, \& Camargo, 2016).

Lesions may appear on corn leaves as small spots or long streaks parallel to the ribs, initially appearing with a light green color and soaking aspect, evolving to necrotic areas that coalesce, can reach large areas easily by the tearing of the leaf. This bacterium can cause rot in the internode near the ear or lead to the death of the plant (White, 1999), which can cause decreased productivity and affect grain quality (Lanza et al., 2016).

The causal agent of this disease is not yet well understood in the literature (Carvalho et al., 2016), but is named by Willems etal.(1992) as Pseudomonas avenae Manns (sin. P. alboprecipitans Rosen and Acidovorax avenae subsp. avenae). What is known is that it is a gram-negative bacilform bacterium with bipolar flagella (Carvalho et al., 2016), and it is favored by hot and humid climates with ideal development temperatures between $30{ }^{\circ} \mathrm{C}$ and 35 ${ }^{\circ} \mathrm{C}$. We also know that it does not survive well in soil or on cultural remains. The use of resistant or tolerant hybrids is currently the best form of control. This pathogen causes diseases in other crops such as rye, barley, wheat, oats, and sorghum (White, 1999).
In addition to the etiology and symptoms presented by the disease, it is important to determine the intensity of symptoms, as well as, to accurately quantify the severity of the disease. Therefore, it is necessary to use diagrammatic scales developed from leaves that show the symptoms and signs of the disease under study (Amorim \& Bergamin, 2018). Consequently, the development of severity levels, that can be reproduced in the field, show a pattern of disease progression, and allow immediate evaluation (Berger, 1980).

To make a diagrammatic scale, it is necessary to prioritize the upper and lower limits of the scale, which must correspond to the maximum and minimum amounts of symptoms found in the field, and include intermediate levels of severity of the disease. One must also take into account the limits of visual acuity of the human being, defined by the Weber-Fechner visual stimulus law (Nutter \& Schultz, 1995).

Before a scale can be proposed, it is important that it be validated to verify whether the result obtained is satisfactory or not. For validation, evaluators need to accurately and precisely estimate the injured area.

There is still no diagrammatic scale for bacterial leaf blight, therefore, it is sought through this study to develop and validate a scale to quantify the severity of this disease caused by Pseudomonas avenae in corn. 


\section{Materials and Methods}

For the elaboration of the scale, leaves of the corn hybrid Supreme with bacterial leaf blight symptoms, presenting different levels of disease severity that resulted from natural infection, were collected. The middle third of each collected leaf was photographed using a digital camera and the images were analyzed with the software Quant-v1 0.0.22 (Vale, Fernandes, \& Liberato, 2001) to calculate the actual severity of the disease by the extent of the leaf area affected.

The levels that make up the proposed scale were determined using the minimum limit, represented by the lowest amount of diseased tissue observed in the field, and the maximum limit characterized by the greatest amount of diseased tissue found. The intermediate levels of severity that were part of the diagrammatic scale were then selected, taking into account Weber-Fechner's law of visual acuity (Horsfall \& Barrat, 1945). Furthermore, considering the shape, distribution, and frequency of the lesions, a diagrammatic scale was made with six levels of severity.

To validate this scale, a presentation was made using the Power Point program (Microsoft Office 2016) with 43 photographs of leaves at different levels of disease severity. These photographs were evaluated by eight people, four of whom were considered to have no experience in the quantification of disease severity (evaluators 1, 2, 3, and 4) and four who were considered experienced as they have already used some type of diagrammatic scale for severity assessment, (evaluators 5, 6, 7, and 8). Each evaluator performed the evaluation twice, without the use of the proposed scale and, subsequently, with the aid of the proposed scale in order to verify its influence on the improvement of estimates.

Graphs presenting the obtained data were made to determine the accuracy of the results. The independent variable $\mathrm{X}$ was defined as the actual severity and the dependent variable $\mathrm{Y}$, the severity estimated by each evaluator. The linear regression analysis method was used, taking into account the slope of the regression line equal to a constant.

The accuracy of the evaluators was determined by the means of the values of the angular and linear coefficients of the linear regression, the first being represented by " $a$ " in the equation, which accompanies " $x$ " and corresponds to the slope of the line indicating that the closer the value is to 1 , the greater the accuracy. Meanwhile, the second corresponds to " $b$ " in the equation and corresponds to the intercept of the linear regression, indicating that the closer the value is to 0 , the greater the accuracy. The accuracy of the evaluators was recorded by the values of the coefficient of determination or correlation $\left(\mathrm{R}^{2}\right)$, which indicate that the closer the values are to 1 , the more accurate are the results obtained from the same linear equation where the values of the angular and linear coefficients were obtained (Nutter \& Schultz, 1995). Absolute errors were obtained by subtracting the estimated severity from the actual severity (Nutter \& Schultz, 1995), without and with the use of the proposed scale.

For statistical analysis of the data, simple regression and $t$ test with a $5 \%$ probability of error were performed. Values of "a" (angular coefficient) different from 1, indicate the occurrence of systematic deviations and values of " $b$ " (linear coefficient) other than 0 , indicate the presence of constant deviations (Alves et al., 2015). Statistical analyses were performed using the free software Genes (Cruz, 2013).

\section{Results and Discussion}

The diagrammatic scale presented six levels of severity and had, as lower and upper limits, the values of $1.5 \%$ and $70 \%$ of the injured area, respectively. The intermediate levels were adjusted for $2.5 \%, 9 \%, 18 \%$, and $46 \%$ severity (Figure 1). Severity values above $70 \%$ were not included in the scale, as these were not observed in the field. 


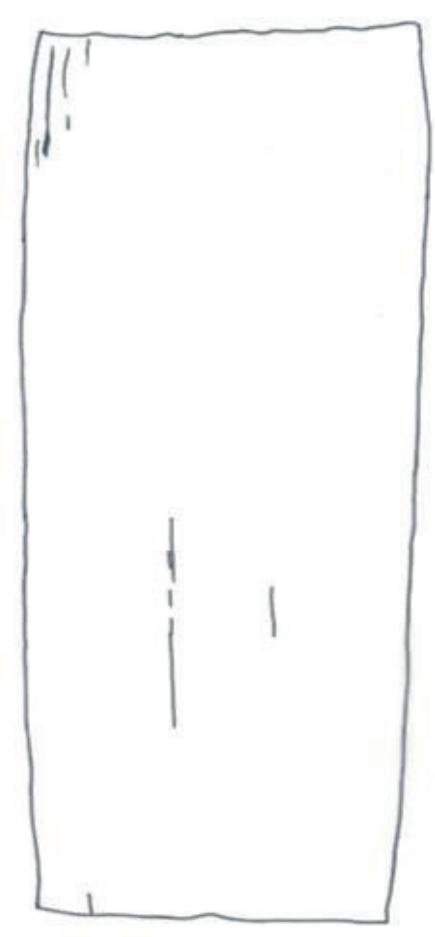

$1.5 \%$

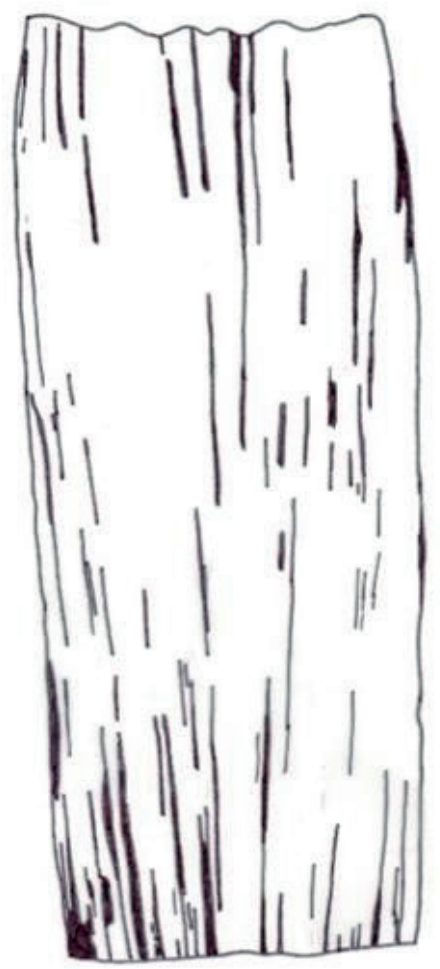

$18.0 \%$
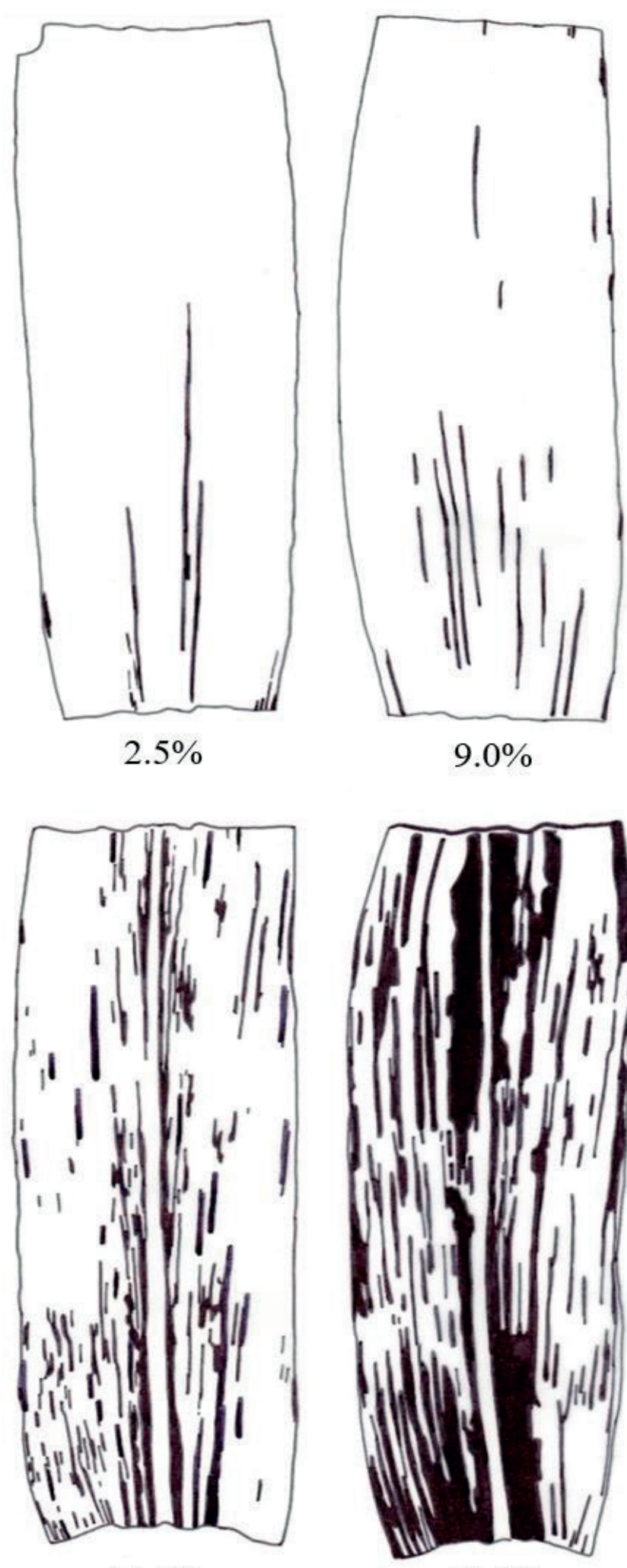

$46.0 \%$

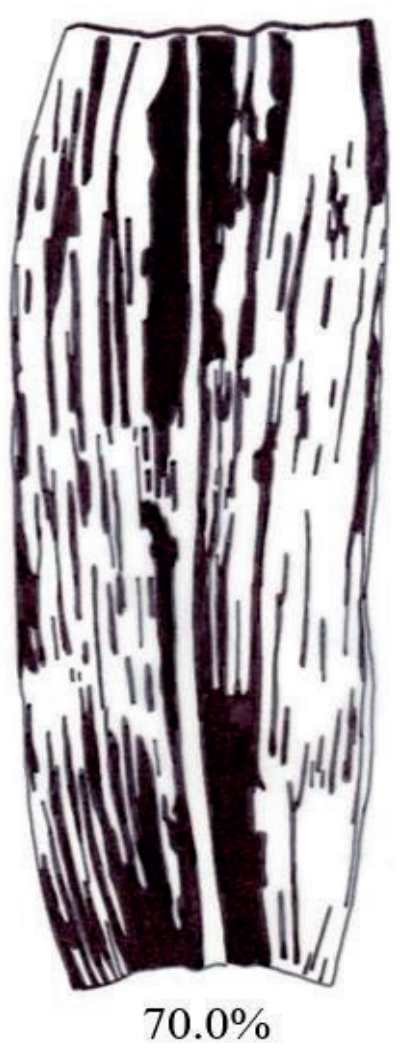

Figure 1. Diagrammatic scale for evaluation of bacterial leaf blight severity in corn (Zea mays L.) caused by Pseudomonas avenae. Values show percentage of leaf area with symptoms. State University of Western Paraná (Unioeste), Campus Marechal Cândido Rondon, 2018. 
For scale validation, we observed the values of the linear equations for each evaluator, four inexperienced and four experienced, with and without the use of the scale.

It can be noted that, in general, accuracy was high with the use of the diagrammatic scale, because the mean values of the angular coefficient of line "a" increased by $22 \%$ among the inexperienced evaluators and $34 \%$ among experienced evaluators, allowing the average to be closer to 1 . For the linear coefficient or intercept " $b$ ", there was an average decrease of $32 \%$ and $68 \%$ in the values for inexperienced and experienced evaluators, respectively. These values became closer to 0 .

Knowing that these coefficients indicate the accuracy of the evaluator, that is, it refers to the proximity between the values of the estimated severity and the values of the actual severity, it can be concluded that there was an increase in the accuracy of the evaluators.
When the values of " $a$ " and " $b$ " deviated from 1 and 0 , respectively, it was an indication of the presence of constant and systematic deviations in the evaluation (Lenz, Balardin, Corte, Marques, \& Debona, 2010).

For inexperienced evaluators, without the use of the diagrammatic scale, errors were present for both the angular coefficient "a" (systematic deviations), as for the linear coefficient " $b$ " (constant deviations) because the values were statistically different from 1 and 0 , respectively. Using the proposed diagrammatic scale, evaluators 1 and 2 had improved accuracy because for the angular coefficient "a" the values became statistically equal to 1 , with no systematic deviations. For evaluator 4 , the linear coefficient became non-significant, also indicating an increase in accuracy due to the decrease in constant deviations. Therefore, for inexperienced evaluators 1,2 , and 4, accuracy was improved with the use of the diagrammatic scale, compared to the values without its use (Table 1).

\section{Table 1}

Angular coefficient (a), linear coefficient (b), and coefficient of determination $\left(\mathbf{R}^{2}\right)$ of the actual linear regression (independent variable) and the estimated severity (dependent variable) for bacterial leaf blight (Pseudomonas avenae) in corn (Zea mays L.), by eight evaluators ( 1 to 4 inexperienced and 5 to 8 experienced), with and without the use of the proposed diagrammatic scale

\begin{tabular}{|c|c|c|c|c|c|c|}
\hline \multirow{2}{*}{ Evaluator } & \multicolumn{3}{|c|}{ Without scale } & \multicolumn{3}{|c|}{ With scale } \\
\hline & $a$ & $b$ & $\mathrm{R}^{2}$ & $a$ & $b$ & $\mathrm{R}^{2}$ \\
\hline \multicolumn{7}{|c|}{ Inexperienced } \\
\hline 1 & $0.7910^{*}$ & $4.3849 *$ & 0.6721 & $0.8706^{\mathrm{ns}}$ & $3.7098^{*}$ & 0.7529 \\
\hline 2 & $0.6738^{*}$ & $9.2701^{*}$ & 0.6569 & $0.9584^{\mathrm{ns}}$ & $5.6745^{*}$ & 0.8315 \\
\hline 3 & $0.6415^{*}$ & $5.9856^{*}$ & 0.4564 & $0.8029^{*}$ & $8.823^{*}$ & 0.799 \\
\hline 4 & $0.5784^{*}$ & $8.2455^{*}$ & 0.5799 & $0.6470^{*}$ & $0.5281 \mathrm{~ns}$ & 0.8961 \\
\hline \multicolumn{7}{|l|}{ Experienced } \\
\hline 5 & $0.874^{\mathrm{ns}}$ & $6.0031 *$ & 0.8197 & $1.0358^{\mathrm{ns}}$ & $0.8209^{\text {ns }}$ & 0.9578 \\
\hline 6 & $0.3549^{*}$ & $2.9454 *$ & 0.6985 & $0.8509^{*}$ & $0.5193^{\mathrm{ns}}$ & 0.9237 \\
\hline 7 & $1.0326^{\mathrm{ns}}$ & $6.4667^{*}$ & 0.8193 & $1.0807^{\mathrm{ns}}$ & $2.7768^{*}$ & 0.9261 \\
\hline 8 & $0.6221 *$ & $4.3115^{*}$ & 0.7676 & $0.8987^{\mathrm{ns}}$ & $2.0419 *$ & 0.9062 \\
\hline
\end{tabular}

* Situation in which the null hypothesis $(\mathrm{a}=1$ or $\mathrm{b}=0$ ) is rejected by the $t$ test, $\mathrm{p}<0.05$. 
Among the experienced, only evaluators 5 and 7 did not present systematic errors for the angular coefficient "a", while the other evaluators for both the angular and linear coefficients presented errors. For evaluator 5, using the proposed diagrammatic scale, the angular coefficient remained non-significant, being equal to 1 , and the linear coefficient that was significant without using the scale (presented constant deviations) became non-significant, that is, statistically equal to zero with the use of the scale. For evaluator 6, only the linear coefficient became non-significant indicating increased accuracy, while evaluator 8 showed improvement in accuracy by eliminating systematic errors in the angular coefficient. Moreover, for evaluator 8, the latter, using the proposed scale, had become nonsignificant, that is equal to 1 . Thus, the experienced evaluators 5, 6, and 8 showed improvement in accuracy with the use of the scale (Table 1).

Taking into account the values of the coefficient of determination $\left(\mathrm{R}^{2}\right)$, there was an increase of $71 \%$ in the accuracy of the estimated severity by inexperienced evaluators and a 19\% increase for the experienced ones. Accuracy indicates the reliability of the assessments by comparing actual and estimated severity values (Lenz et al., 2010).

For both experienced and inexperienced evaluators, there was an increase in accuracy with the use of the proposed diagrammatic scale (Table 1, and Figures 2 and 3).

According to Mafia, Ferreira, Binoti and Leite (2011), $\mathrm{R}^{2}$ values of up to 0.70 are considered low, thus, all inexperienced evaluators who did not use the proposed diagrammatic scale and experienced evaluator 6 who presented low precision, were corrected with the use of the proposed diagrammatic scale. These results corroborate those of other validation studies of diagrammatic scales where there was an increase in the accuracy of visual evaluations of disease severity when using the proposed diagrammatic scales (Acco, Gomes, Matos, Ribeiro \& Balbi-Peña, 2020; Alves et al., 2015; Nunes \& Alves, 2012; Trojan \& Pria, 2018).
According to Vivas, Terra, Silveira, Fontes and Pereira (2010) as well as Nunes \& Alves (2012), an important factor in verifying whether or not the estimates presented convenient values of accuracy, is the observation of the variance of absolute errors. Figures 4 and 5 show that the absolute errors of severity estimated by inexperienced evaluators without using the proposed scale, were both positive and negative, presenting great disuniformity, with no trend observed. However, with the use of the scale, only evaluator 4 showed positive values indicating overestimated severity levels, while all inexperienced evaluators presented values closer to the line, that is closer to zero, decreasing absolute errors.

For the experienced evaluators, it is possible to verify that without the use of the diagrammatic scale (Figure 4), evaluators 5 and 7 presented predominantly negative absolute error values, which shows a tendency to underestimate the severity values, which were maintained using diagrammatic scales (Figure 5). Nevertheless, these values were closer to zero.

For evaluator 6, without using the scale (Figure 4), there was an overestimation of the severity levels, which were maintained using the diagrammatic scale (Figure 5), but with greater approximation of zero. Similarly, for evaluator 8 , who overestimated severity levels without using the diagrammatic scale (Figure 4), that is, presented predominantly positive values; with the use of the proposed scale there was an end to this trend of overestimation, and both negative and positive values were presented (Figure 5).

Considering human perception, according to Sherwood, Berg, Hoover and Zeiders (1983), there is usually a tendency to overestimate severity values when there is a greater number of small lesions compared to diseases that induce large lesions. In this study, this occurred in only a portion of the evaluators, which evidences the existence of differing perspectives among evaluators as each has their own specificities. 


\section{Evaluator 1}

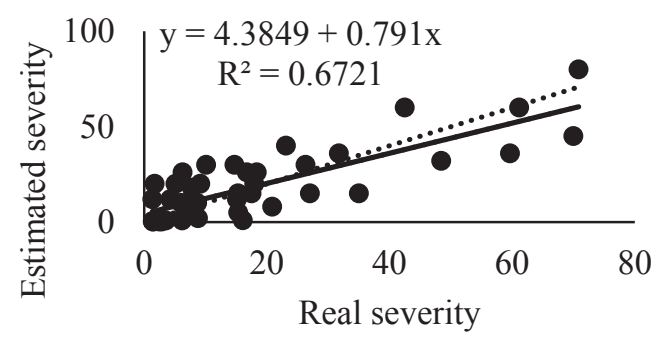

Evaluator 2

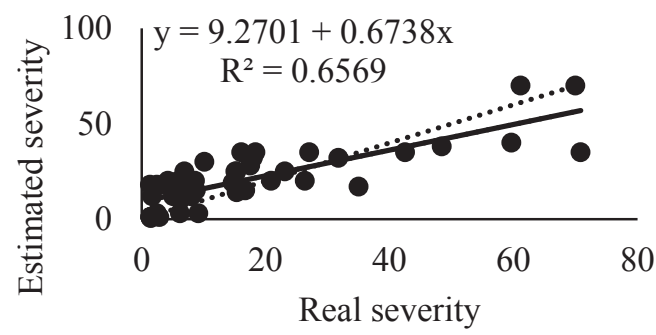

Evaluator 3

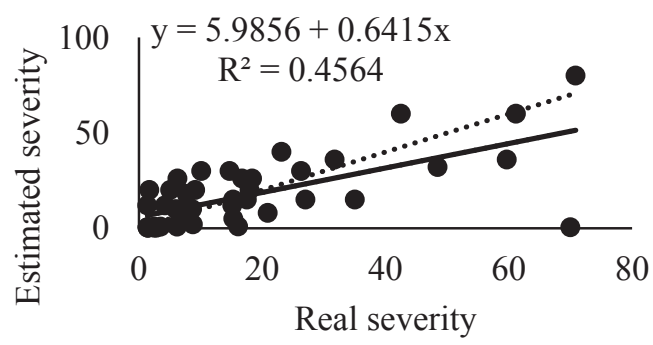

Evaluator 4

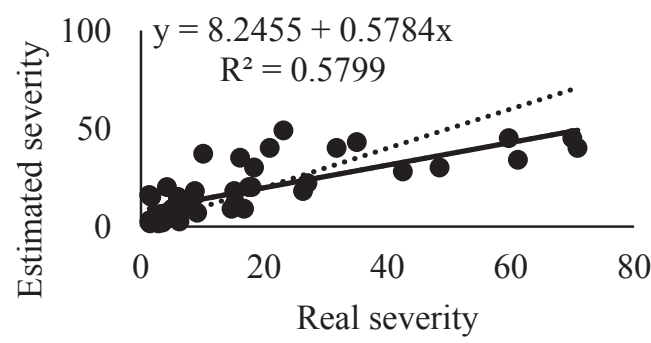

Evaluator 5

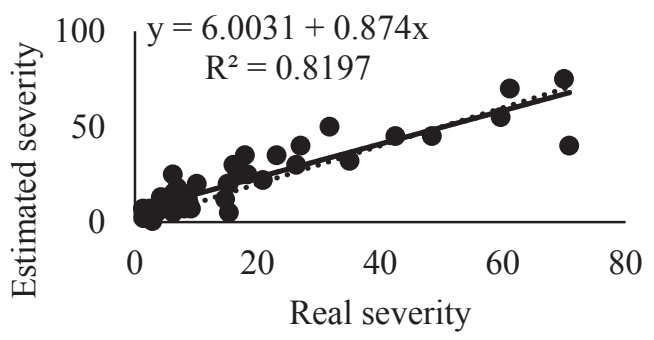

Evaluator 6

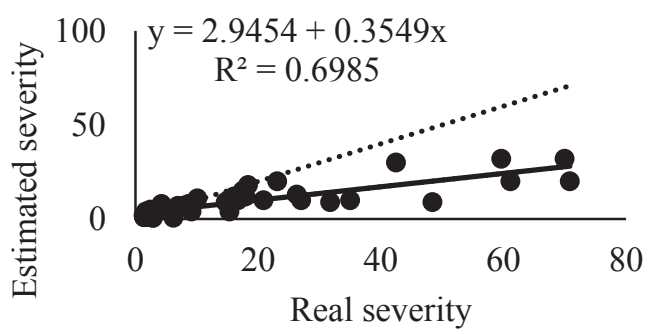

Evaluator 7

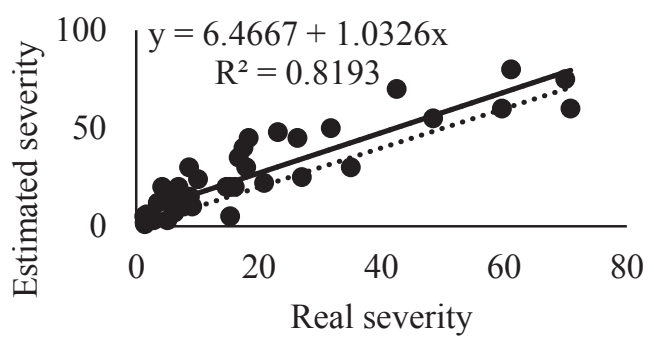

Evaluator 8

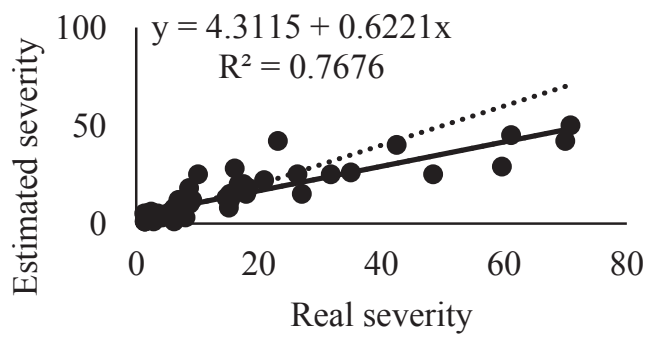

Figure 2. Severity $(\%)$ estimated without the aid of the elaborated diagrammatic scale $(\bullet)$ and linear regression obtained between actual and estimated severities represented by the continuous line (-) from evaluating bacterial leaf blight (Pseudomonas avenae) in corn (Zea mays L.). The dotted line (*) represents the ideal situation, with severity estimates identical to the actual one. Evaluators 1 to 4 are inexperienced and evaluators 5 to 8 are experienced. 


\section{Evaluator 1}

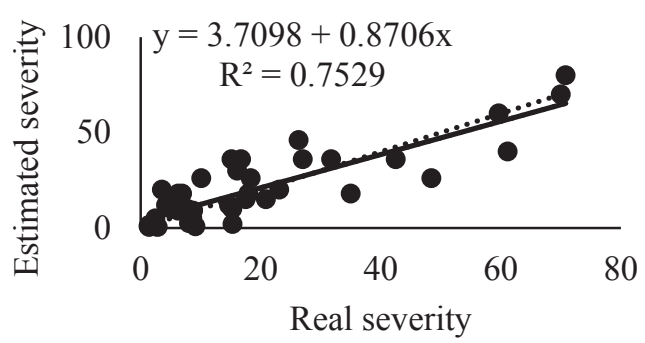

Evaluator 2

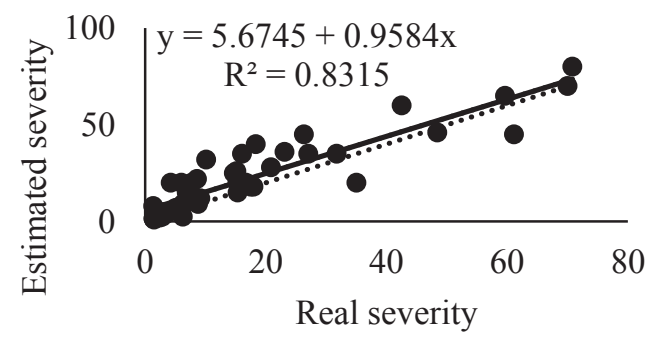

Evaluator 3

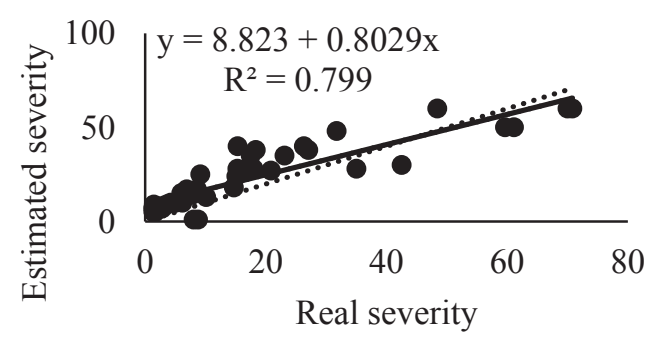

Evaluator 4

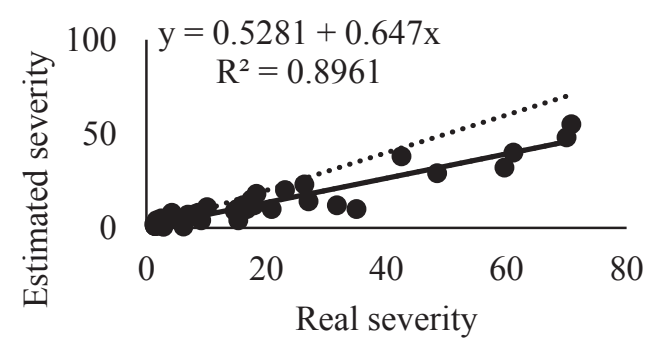

\section{Evaluator 5}

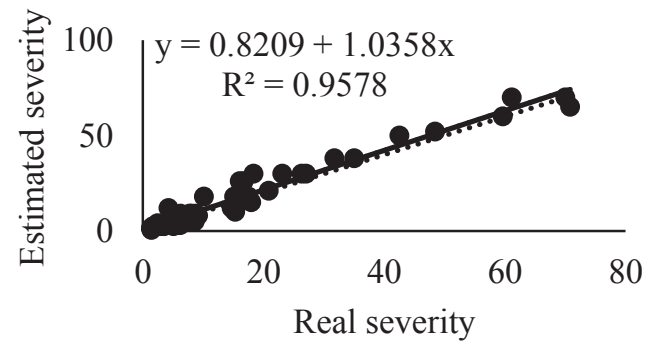

Evaluator 6

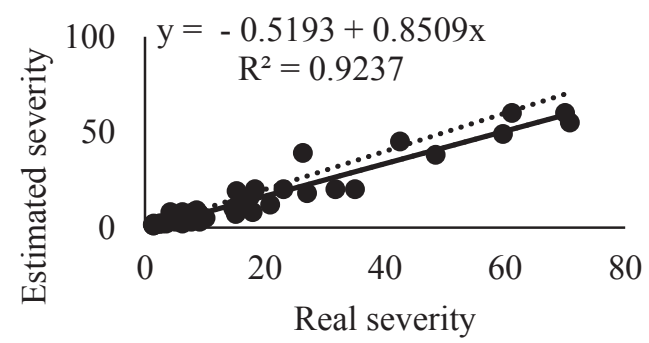

Evaluator 7

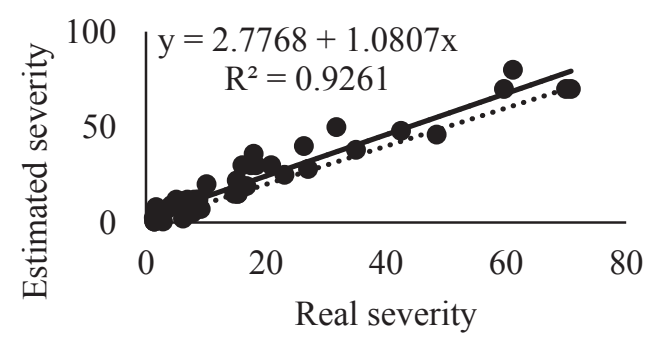

Evaluator 8

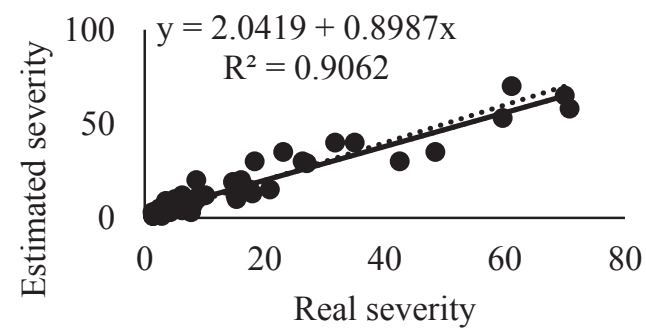

Figura 3. Severity $(\%)$ estimated with the aid of the elaborated diagrammatic scale $(\bullet)$ and linear regression obtained between the actual and the estimated severities represented by the continuous line (-) from evaluating bacterial leaf blight (Pseudomonas avenae) in corn (Zea mays L.). The dotted line (*) represents the ideal situation, with severity estimates identical to the actual one. Evaluators 1 to 4 are inexperienced and evaluators 5 to 8 are experienced. 
Evaluator 1

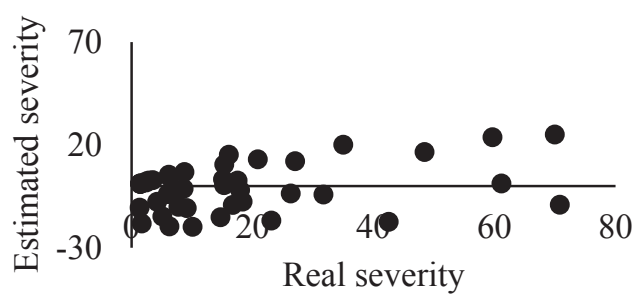

Evaluator 2

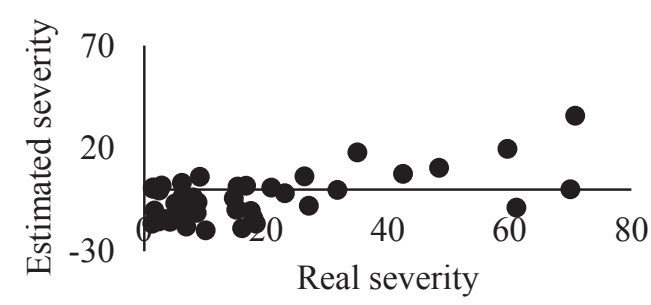

Evaluator 3

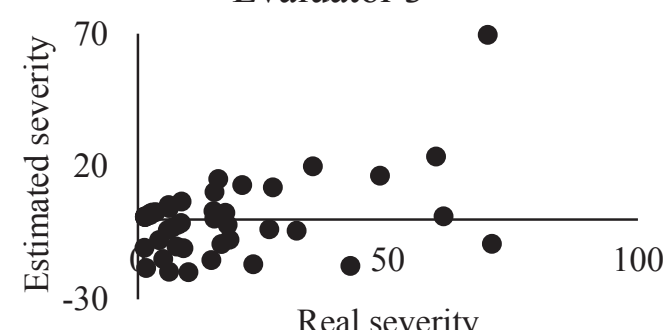

Evaluator 4

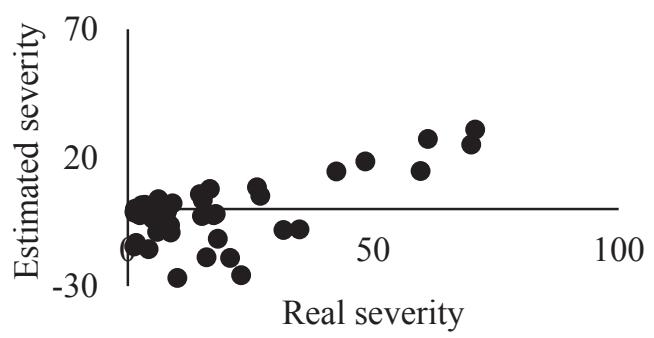

Evaluator 5

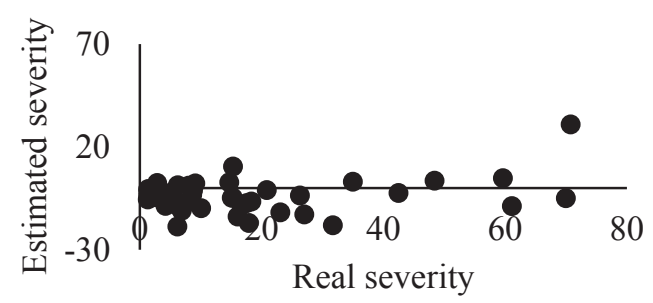

Evaluator 6

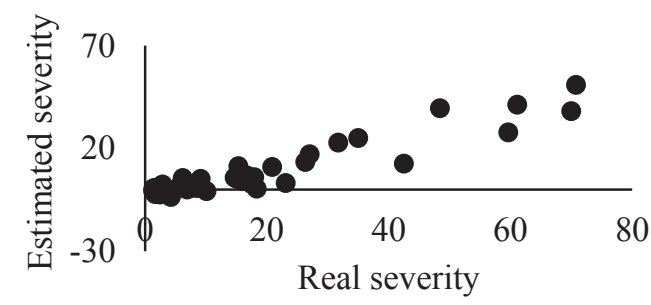

Evaluator 7

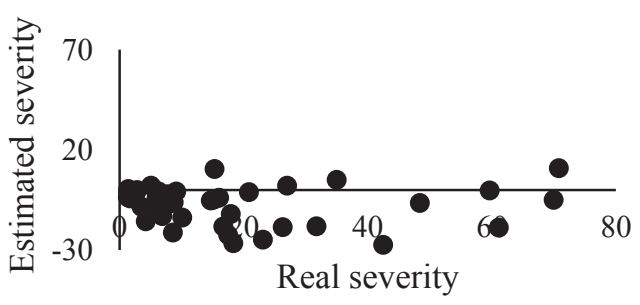

Evaluator 8

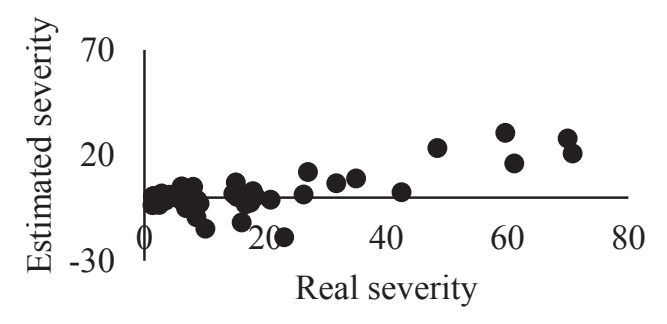

Figure 4. Absolute errors (estimated severity minus actual severity) of bacterial leaf blight assessments (Pseudomonas avenae) in corn (Zea mays L.). Evaluations made without using the proposed diagrammatic scale. Evaluators 1 to 4 are inexperienced, i.e., have never used a diagrammatic scale and evaluators 5 to 8 are experienced, i.e. have already used a diagrammatic scale. 


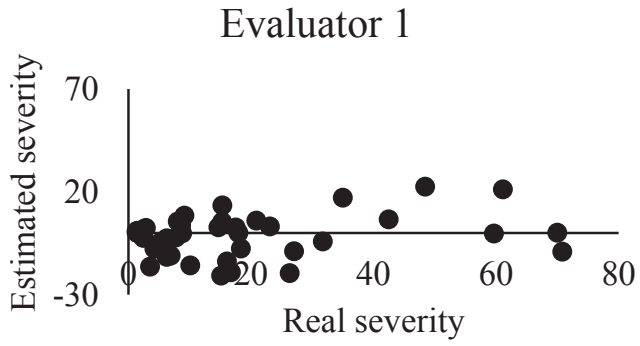

Evaluator 2

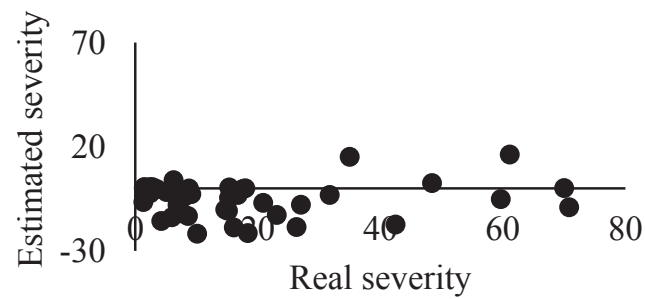

Evaluator 3

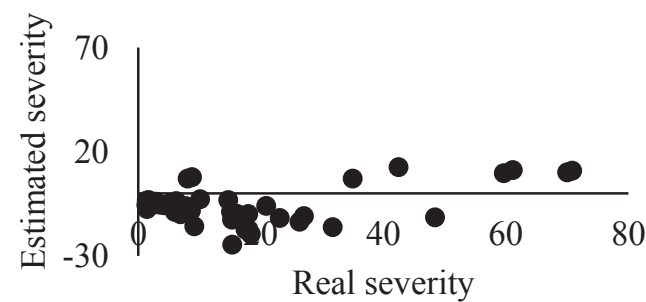

Evaluator 4

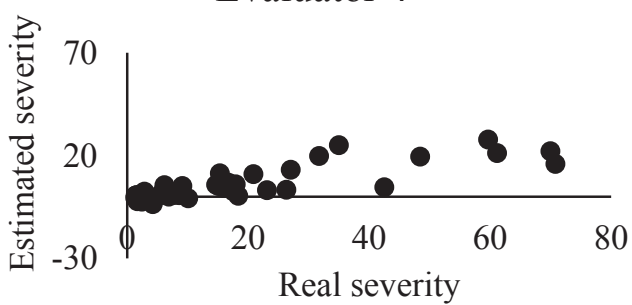

Evaluator 5

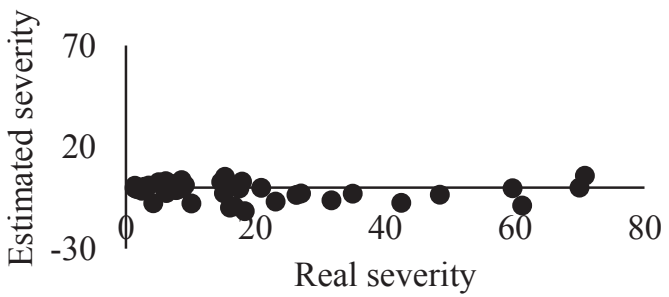

Evaluator 6

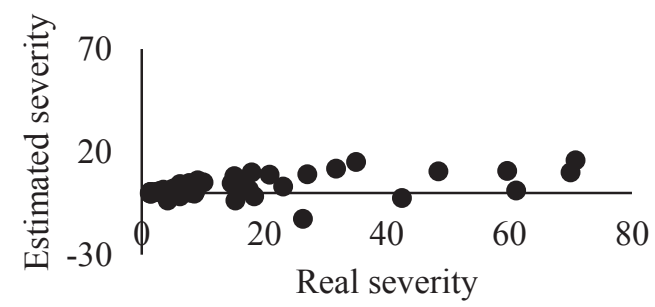

Evaluator 7

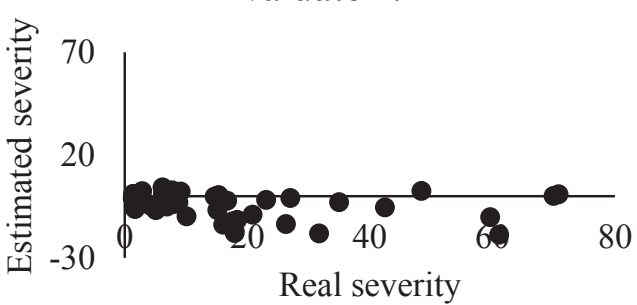

Evaluator 8

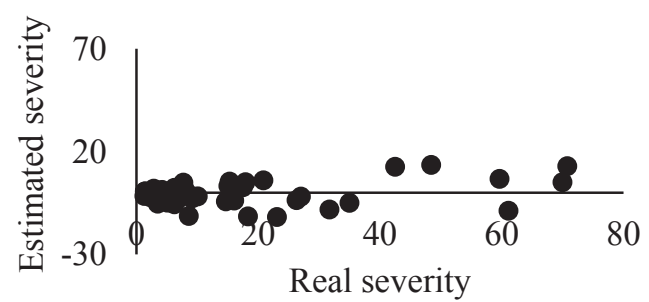

Figure 5. Absolute errors (estimated severity minus actual severity) of bacterial leaf blight assessments (Pseudomonas avenae) in corn (Zea mays L.) using the proposed diagrammatic scale. Evaluators 1 to 4 are inexperienced, i.e. have never used a diagrammatic scale and evaluators 5 to 8 are experienced, i.e. have already used a diagrammatic scale.

A particular evaluator may experience interference in estimates due to the complexity of the shape of the lesions, or fatigue and lack of concentration during work, which can cause their perception and visual stimuli to change (Sachs, Neves, Canteri, \& Sachs, 2011).
Without the use of the diagrammatic scale, the absolute errors for inexperienced evaluators ranged from -25.87 to 69.51 (Figure 4); while with the use of the scale, absolute errors decreased to values ranging from -24.65 to 27.68 (Figure 5). Among the experienced evaluators, without the use of the 
scale, absolute errors were recorded from -27.98 to 50.83 (Figure 4). However, after using the diagrammatic scale, there was a reduction in these errors, which were between the values of -12.66 and 15.83 (Figure 5).

The results obtained demonstrate the relevance of the use of diagrammatic scales because the overestimation or underestimation of severity is reduced (Lazaroto, Santos, Konflanz, Malagi, \& Camochena, 2012). Furthermore, errors can be further minimized with evaluator training and consistent use of the proposed scale (Amorim \& Bergamin, 2018).

\section{Conclusion}

The use of the developed diagrammatic scale resulted in higher accuracy of severity estimates, constituting an efficient tool to quantify the severity of bacterial leaf blight of corn leaves caused by $P$. avenae.

\section{References}

Acco, L. F., Gomes, D. G., Matos, J. N., Ribeiro, N. R., \& Balbi-Peña, M. I. (2020). Elaboração e validação de escala diagramática para avaliação da pústula bacteriana em soja. Summa Phytopathologica, 46(2), 145-149. doi: 10.1590/0100-5405/211476

Alves, G. C. S., Santos, L. C., Duarte, H. S. S., Dias, V., Zambolim, L., \& Rocha, M. R. (2015). Escala diagramática para quantificação da ferrugem da folha do trigo. Multi-Science Journal, 1(1), 128-133. doi: 10.33837/msj.v1i1.59 Recuperado de https://www. ifgoiano.edu.br/periodicos/index.php/ multiscience/ article/view/59

Amorim, L., \& Bergamin, A. F. (2018). Fenologia, patometria e quantificação de danos. In L. Amorin, J. A. M. Rezende, \& A. Bergamin, Fo. (Eds.), Manual de fitopatologia: princípios de conceitos (pp. 499518). Ouro Fino, MG: Ceres.

Berger, R. D. (1980). Measuring disease intensity. In P. S., Teng, \& S. V. Krupa (Eds.), Crop loss assessment (pp. 28-31). Saint Paul, Minnesota: University of Minnesota.
Carvalho, R. V., Pereira, O. A. P., \& Camargo, L. E. A. (2016). Doenças do milho. In L, Amorim, J. A. M. Rezende, A. Bergamin $\mathrm{F}^{\circ}$, \& L. E. A Camargo (Eds.), Manual de fitopatologia: doenças das plantas cultivadas (pp. 549-560). Ouro Fino, MG: Ceres.

Cruz, C. D. (2013). Genes: a software package for analysis in experimental statistics and quantitative genetics. Acta Scientiarum. Agronomy, 35(3), 271-276. doi: 10.4025/actasciagron.v35i3.21251 Retrieved from http://www.scielo.br/pdf/asagr/v35n3/v35n3a01.pdf

Horsfall, J. C., \& Barratt, R. W. (1945). An improved grading system for measuring plant diseases. Phytopathology, 35, 665-665. Retrieved from http://www.garfield.library.upenn.edu/classics1986/ A1986A666500001.pdf

Lanza, F. E., Zambolim, L., Costa, R. V., Silva, D. D., Queiroz, V. A. V., Parreira, D. F., Cota, L. V. (2016). Aplicação foliar de fungicidas e incidência de grãos ardidos e fumonisinas totais em milho. Pesquisa Agropecuária Brasileira, 51(5), 638-646. doi: 10.1590/S0100-204X2016000500026 Recuperado de https://ainfo.cnptia.embrapa.br/digital/bitstream/ item/146150/1/Aplicacao-foliar-de-fungicidas.pdf

Lazaroto, A., Santos, I., Konflanz, V., Malagi, G., \& Camochena, R. C. (2012). Escala diagramática para avaliação de severidade da helmintosporiose comum em milho. Ciência Rural, 42(12), 2131-2137. doi: 10.1590/S0103-84782012005000112 Recuperado de http://www.scielo.br/pdf/cr/v42n12/a34912cr 6772.pdf

Lenz, G., Balardin, R. S., Corte, G. D., Marques, L. N., \& Debona, D. (2010). Escala diagramática para avaliação de severidade de mancha-parda em arroz. Ciência Rural, 40(4), 752-758. doi: 10.1590/S010384782010005000061 Recuperado de http://www. scielo.br/pdf/cr/v40n4/a539cr2706.pdf

Mafia, R. G., Ferreira, M. A., Binoti, D. H. B., \& Leite, H. G. (2011). Procedimento estatístico para validação de escalas diagramáticas na quantificação de doenças. Revista Árvore, 35(2), 199-204. doi: 10.1590/S010067622011000200004 Recuperado de http://www. scielo.br/pdf/rarv/v35n2/a04v35n2.pdf

Nunes, C. C., \& Alves, S. A. M. (2012). Elaboração e validação de escala diagramática para quantificação da severidade de entomosporiose em folhas de pereira. Summa Phytopathologica, 38(3), 239244. doi: 10.1590/S0100-54052012000300011 Recuperado de http://www.scielo.br/pdf/sp/v38n3/ a11v38n3.pdf 
Nutter, F. W., Jr., \& Schultz, P. M. (1995). Improving the accuracy and precision of disease assessments: selectionofmethodsanduseofcomputer-aided training programs. Canadian Journal of Plant Pathology, 17(2), 174-184. doi: 10.1080/07060669509500709 Retrieved from https://www.tandfonline. com/doi/ abs/10.1080/07060669509500709

Sachs, P. D., Neves, C. J., Canteri, M. G., \& Sachs, L. G. (2011). Escala diagramática para avaliação da severidade da mancha branca em milho. Summa Phytopathologica, 37(4), 202-204. doi: 10.1590/ S0100-54052011000400007 Recuperado de http:// www.scielo.br/pdf/sp/v37n4/a07v37n4.pdf

Sherwood, R. T., Berg, C. C., Hoover, M. R., \& Zeiders, K. E. (1983). Illusions in visual assessment of stagonospora leaf spot of orchardgrass. Phytopathology, 73(2), 173-177. doi: 10.1094/ phyto-73-173 Retrieved from https://www.apsnet. org/publications/phytopathology/backissues/ Documents/1983 Articles/Phyto73n02_173.PDF

Trojan, D. G., \& Pria, M. D. (2018). Validação de escala diagramática para quantificação da severidade da antracnose da folha do milho. Summa Phytopathologica, 44(1), 56-64. doi: 10.1590/01005405/172675 Recuperado de http://www.scielo.br/ pdf/sp/v44n1/0100-5405-sp-44-1-0056.pdf
Vale, F. X. R., Fernandes, E. I. F., F., \& Liberato, J. R. (2001). QUANT: software to quantify plant disease severity. Proceedings of the International Workshop on Plant Disease Epidemiology, Ouro Preto, MG, Brazil, 8.

Vivas, M., Terra, C. E. P. S., Silveira, S. F., Fontes, R. V., \& Pereira, M. G. (2010). Escala diagramática para avaliação da severidade de pinta-preta em frutos de mamoeiro. Summa Phytopathologica, 36(2), 161163. doi: $10.1590 / 0100-5405 / 178543$ Recuperado de http://www.scielo.br/pdf/sp/v44n3/0100-5405sp-44-3-0252.pdf

White, D. G. (1999). Compendium of corn diseases. Saint Paul, Mineesota: American Phytopathological Society.

Willems, A., Goor, M., Thielemans, S., Gillis, M., Kersters, K. E., \& Ley, J. (1992). Transfer of several phytopathogenic Pseudomonas species to Acidovorax avenae subsp. avenae subsp. nov. comb. nov., Acidovorax avenae subsp. citrulli, Acidovorax avenae subsp. cattleyae, and Acidovorax konjaci. International Journal of Systematic Bacteriology, 42(1), 107-119. doi: 0020-7713/92/010107-13\$02 https://www.microbiologyresearch.org/docserver/ fulltext/ijsem/42/1/ijs-42-1-107.pdf?expires $=15593$ $10202 \& \mathrm{id}=\mathrm{id} \&$ accname $=$ guest $\&$ checksum $=6 \mathrm{~A} 0 \mathrm{~EB}$ A5B39E3FFD2E611A4B9D5EF4B67 